\title{
Perpustakaan Sebagai Teropong Profesionalisme Pustakawan
}

\author{
Aris Nurohman \\ Pustakawan Institut Agama Islam Negeri Purwokerto \\ Email: aris@iainpurwokerto.ac.id
}

\begin{abstract}
Library is an institution that can not be separated from the role of librarians. Library dependence to the librarian is seen almost in the whole library complexity. Starting from planning, organizing, leadership, and control. Through this writing the authors will contribute a more real attachment between librarians and libraries. Based on some literature proves that between librarian and library can not stand alone. Starting from the management, service products and aspects of library accreditation assessment, librarians are instrumental in contributing enormously. Because of this dependence illustrates that the quality of the library will be seen from the quality of the librarian profession.
\end{abstract}

Key Words: Librarian, Library, Professional, Profession, Service

\begin{abstract}
Abstrak
Perpustakaan adalah lembaga yang tidak dapat dipisahkan dari peran pustakawan. Ketergantungan perpustakaan kepada pustakawan terlihat hampir di seluruh kompleksitas perpustakaan. Mulai dari perencanaan, pengorganisasian, kepemimpinan, dan kontrol. Melalui penulisan ini penulis akan menyumbangkan keterikatan yang lebih nyata antara pustakawan dan perpustakaan. Berdasarkan beberapa literatur membuktikan bahwa antara pustakawan dan perpustakaan tidak bisa berdiri sendiri. Mulai dari manajemen, produk layanan dan aspek penilaian akreditasi perpustakaan, pustakawan berperan dalam memberikan kontribusi besar. Karena ketergantungan ini menggambarkan bahwa kualitas perpustakaan akan terlihat dari kualitas profesi pustakawan.
\end{abstract}

Kata Kunci : Pustakawan, Perpustakaan, Profesi

\section{A. PENDAHULUAN}

Jika kita pahami definisi perpustakaan menurut undang-undang nomor 43 tahun 2007, maka setidaknya syarat utama perpustakaan ada 3, yaitu wadah, sumber daya dan produk. Wadah secara bahasa adalah tempat untuk menaruh atau menyimpan. Dalam konteks perpustakaan, wadah dimaknai sebuah tempat yang wujud terlihat berupa gedung atau ruang,

Tik Ilmeu : Jurnal Ilmu Perpustakaan dan Informasi

Perpustakaan STAIN Curup | p-issn: 1496125591; e-issn:1496125960 
maupun tempat yang tidak wujud terlihat kasat mata yaitu lembaga, institusi atau organisasi. Kecil atau besar perpustakaan adalah institusi yang berada didalam sebuah ruang atau gedung.

Pengertian kedua bahwa perpustakaan sebagai institusi pengelola karya tulis, karya cetak dan atau karya rekam secara professional dengan system baku. Setidaknya terdapat dua komponen untuk memenuhi syarat pengelolaan, yaitu bahan yang dikelola (bahan perpustakaan) dan orang yang mengelola (pustakawan). Kedua faktor ini dalam istilah lain disebut sebagai sumber daya yang digunakan untuk mencapai hasil atau tujuan tertentu. Meski tidak secara eksplisit menyebutkan jenis sumber daya, namun kita bisa memahami bahwa maknanya mengarah pada bahan perpustakaan dan pustakawan. Dalam konteks organisasi, pengelolaan disebut juga dengan istilah lain sebagai manajemen.

Adapun produk adalah hasil dari aktifitas yang telah dilakukan oleh pustakawan sebagai sumber daya manusia yang melakukan pengelolaan terhadap bahan perpustakaanya dan berada di sebuah tempat dibawah nama institusi perpustakaan. Perpustakaan menghasilkan produk berupa jasa untuk memenuhi kebutuhan pendidikan, penelitian, pelestarian, informasi dan bahkan rekreasi.

Dengan demikian, perpustakaan merupakan satu kesatuan yang tidak dipisahkan dari institusi, gedung, koleksi, dan pustakawan. Melihat perpustakaan dapat dilihat dari komponen perpustakaan. Mengutip K.G. Saur (2008: 16) mengatakan the existing performance indicators have been devised, tested and selected by librarian. That means that they reflect the librarian's picture of deal library. Indikator kinerja (perpustakaan) telah dirancang, diuji dan dipilih oleh pustakawan. Interaksinya merefleksikan ikatan antara pustakawan dengan perpustakaan. Pendapat ini mempertegas peran pustakawan dalam segala aktifitas di perpustakaan. Oleh karena itu, menarik untuk dikaji lebih mengenai artikulasi hubungan antara profesionalitas pustakawan dan kualitas perpustakaannya.

\section{Definisi dan Komponen Perpustakaan}

Menurut Sulistyo Basuki yang dikutip oleh Lasa (2005: 147), mendefinisikan perpustakaan adalah ruangan, bagian sebuah gedung atau gedung itu sendiri yang digunakan untuk menyimpan buku dan terbitan lainnya, disimpan menurut tata susunan tertentu, digunakan untuk pembaca dan bukan untuk dijual. 
Dalam undang-undang nomor 43 tahun 2007 disebutkan bahwa Perpustakaan adalah institusi pengelola koleksi karya tulis, karya cetak, dan/atau karya rekam secara profesional dengan sistem yang baku guna memenuhi kebutuhan pendidikan, penelitian, pelestarian, informasi, dan rekreasi para pemustaka.

Dua definisi tersebut memberikan penjelasan tentang beberapa komponen yang harus ada di perpustakaan yaitu:

1. Gedung/ ruang;

2. Koleksi atau bahan perpustakaan ;

3. Sumber daya, baik SDM/ Pustakawan maupun sumber daya lainnya (peralatan, dana dan lainnya);

4. Sistem yang digunakan sebagai pendukung kerja kepustakawanan;

5. Orientasi untuk memenuhi kebutuhan pengguna/ pemustaka.

Semua komponen ini meruakan satu kesatuan yang membentuk sebuah bangunan yang disebut perpustakaan. Sehingga ada ketergantungan antara satu komponen dengan komponen lainnya. Dalam artian bahwa jika salah satu komponen tersebut berkurang atau tidak ada, maka bangunan yang disebut perpustakaan itu sudah mulai runtuh. Sebagai contoh, jika dari kelima itu kemudian syarat pertama tidak ada, maka tidak bisa disebut perpustakaan. Atau jika kemudian komponen SDM pustakawannya ternyata tidak ada, maka juga akan potensial meruntuhkan bangunan perpustakaan. inilah yang disebut sebagai satu kesatuan utuh sendi keberlangsungan sebuah institusi dengan nama perpustakaan.

\section{Profesi dan Profesionalisme Pustakawan}

Memahami istilah profesi yang paling mudah adalah dari asal katanya. Profesi dari akar kata profesion (Ing.), artinya pekerjaan, pernyataan. Dari akar kata professio (Lat.) diartikan sebagai pengikraran. Secara sederhana, definisi etimologi ini mengisyaratkan makna tentang pernyataan atau pengikraran pada satu pekerjaan tertentu. Oleh karena itu seorang yang berprofesi berarti seorang yang menekuni bidang pekerjaan tertentu dan menganggap dirinya menguasai pekerjaannya sehingga ada keberanian mengikrarkan diri atau membuat pernyataan tentang apa yang dikuasainya.

Dalam konteks lain, profesi diartikan sebagai suatu pekerjaan yang mempersyaratkan pendidikan bagi pelakunya dengan titik tekan pada pekerjaan mental bukan pekerjaan manual. Kemampuan mental dimaksud 
adalah persyaratan pengetahuan teoritis sebagai instrumen untuk melakukan pekerjaan praktis (Sudarwan Danim, 2012: 102).

Adapun turunan dari istilah profesi adalah profesional dan profesionalisme. Kata profesional ini merujuk kepada orang atau pekerjaan. Misalnya, Andi seorang profesional. Ia bekerja secara profesional. Dengan demikian profesional dapat diartikan dalam dua makna yang berbeda, yaitu pertama adalah bentuk abstrak sebuah kata benda dari profesi, jadi seorang dokter bisa disebut seorang profesional saja tenpa menyebutkan kata dokter, seorang pustakawan bisa disebut dengan profesional saja tanpa kata pustakawan dan sebaginya. Kedua, profesional adalah bentuk sifat dari suatu pekerjaan tertentu. Pekerjaan dikerjakan secara profesional memiliki sifat yang khas seperti cepat, tepat, benar dan tertruktur.

Sedangkan profesionalisme berasal dari istilah profesional. Menurut Purwono $(2014 ; 1.5)$, profesionalisme dapatdipandang sebagai spirit atau bahkan sikap hidup yang dimiliki individu dan atau kelompok yang menempatkan pekerjaan sebagai hal yang perlu dijalankan dengan penuh tanggung jawab dan seoptimal mungkin. Profesional adalah suatu paham yang mencitakan dilakukannya kegiatan-kegiatan kerja tertentu dalam masyarakat, berbekal keahlian yang tinggi dan berdasarkan rasa keterpanggilan.

Lebih lanjut Wignjosoebroto (1999) sebagaimana dikutip oleh Purwono (2014: 1.6) menjabarkan prefesionalisme dalam tiga watak kerja yaitu: 1. Beritikad baik untuk merealisasikan kebajikan demi tegaknya kehormatan profesi yang digeluti; 2. Dilandasi kemahiran teknis yang berkualitas tinggi yang dicapai melalui pendidika dan atau pelatihan yang panjang, ekslusif dan berat; 3. Diukur dengan kualitas teknis dan kualitas moral.

Adapun ciri profesional menurut Purwono (2014: 1.7) adalah:

1. Keterampilan yang tinggi dalam suatu bidang serta kemahiran dalam menggunakan peralatan tertentu yang diperlukan dalam pelaksanaan tugas yang bersangkutan dalam bidangnya;

2. Ilmu dan pengalaman serta kecerdasan dalam menganalisis suatu masalah dan peka di dalam membaca situasi cepat dan tepat serta cermat dalam mengambil keputusan terbaik atas dasar kepekaan;

3. Sikap berorientasi ke depan sehingga punya kemampuan mengantisipasi perkembangan lingkungan yang terbentang di hadapannya; 
4. Sikap mandiri berdasarkan keyakinan akan kemampuan pribadi serta terbuka menyimak dan menghargai pendapat orang lain, namun ceremat dalam memilih yang terbaik bagi dirinya dan perkembangan pribadinya.

Dari pengertian dan ruang lingkupnya dapat penulis simpulkan bahwa pada dasarnya setiap profesi memiliki ciri khas baik dari sisi kompetensi maupun ruang lingkup pekerjaan jabatannya. Termasuk pustakawan dengan kompetensi kepustakawanan dengan ruang lingkup kinerja di lingkungan perpustakaan. Spesialisasi keahlian dan ketrampilan dibidang kepustakawanan sebenarnya menuntut kreatifitas yang tinggi bagi pengembangan profesi sekaligus menjadi bagian dari kekuatan institusi. Hal ini bisa tercapai jika pustakawan memiliki kepribadian dinamis dan berpandangan berkemajuan terhadap profesi yang digelutinya. Selagi ini disadari, maka akan banyak karya dan produk kreatif yang dapat dihasilkan oleh para pustakawan yang berdampak pada lingkungannya, dan institusi perpustakaanya.

Kita yakin apapun profesinya, menginginkan unggul (valuable) pada bidangnya. Unggul memiliki makna karena dibutuhkan banyak pihak atau dikagumi karena memiliki keistimewaan tertentu. Keunggulan ini akan dapat tercapai jika ia dapat memberikan kontribusi yang berarti kepada pihak lain selaku penerima manfaat atas profesinya itu.

Profesi pada hakekatnya adalah gambaran dinamisasi dalam keahlian tertentu, termasuk karir pada jabatan pustakawan. Agar profesi pustakawan dipandang sebagai karir yang dinamis, inovatif dan kreatif, maka harus dikelola melalui suatu perencanaan yang cermat, karena jika tidak maka berbagai kesempatan karir akan banyak tidak dimanfaatkan (Handoko, 2001: 121).

\section{Metodologi}

Penulisan ini merupakan kajian kepustakaan, sehingga metode yang dipergunakan adalah sebagai berikut:

1. Prosesnya dimulai dengan menyusun asumsi dasar dan pola berpikir yang akan relevan dengan tema besar. Asumsi dan pola berpikir tersebut secara sistematis dipakai dalam menemukan data-data dari berbagai literature dan kemudian mengolahnya. Namun penting untuk dijadikan sebagai pijakan dalam pengumpulan data dan pengolahannya adalah tentang obyektifitas penulis terhadap konten tulisan atau sumber 
data yang didapatnya. Dalam bahasa penelitian, penulisan ini merupakan bentuk penelitian kualitatif.

2. Untuk menghasilkan sebuah kajian yang benar dan obyektif, membutuhkan data-data yang relevan. Data tersebut kemudian diramu sesuai kaidah sebagaimana dalam penelitian kepusakaan (library research). Menurut Muhajir (2011: 335), penelitian kepustakaan (library research) adalah sebuah metode pengumpulan data berdasarkan sumber-sumber dari kepustakaan.

3. Untuk menganalisisnya dilakukan melalui metode analisis isi (content analysis), yaitu analisis terhadap isi pembahasan secara mendalam dari informasi tertulis atau tercetak dalam dari berbagai sumber yang relevan. Metode analisi isi dilakukan untuk mengambil kesimpulan dengan mengidentifikasi berbagai karakteristik khusus suatu pesan secara obyektif, sistematis dan generalis. Teknik yang diterapkan diantaranya, mengumpulkan data-data referensi menyangkut perpustakaan dan pustakawan. Kemudian dikupas satu per satu, diperjelas dengan argumentasi yang mapan dan teori yang sudah ada. Kemudian membuat asumsi dari sebuah pembahasan, menarik relevansi dan juga menemukan suatu penjelasan baru. Terakhir melakukan analisis terhadap semua data yang sudah diperolah dengan menggali makna tekstual dan kontekstual secara benar dan dapat dipertanggungjawabkan secara ilmiah.

Kerangka berpikir pengkajiannya terdiri dari tigas aspek yang saling terkait yaitu:

- Manajemen organisasi

- Produk Jasa

- Akreditasi 


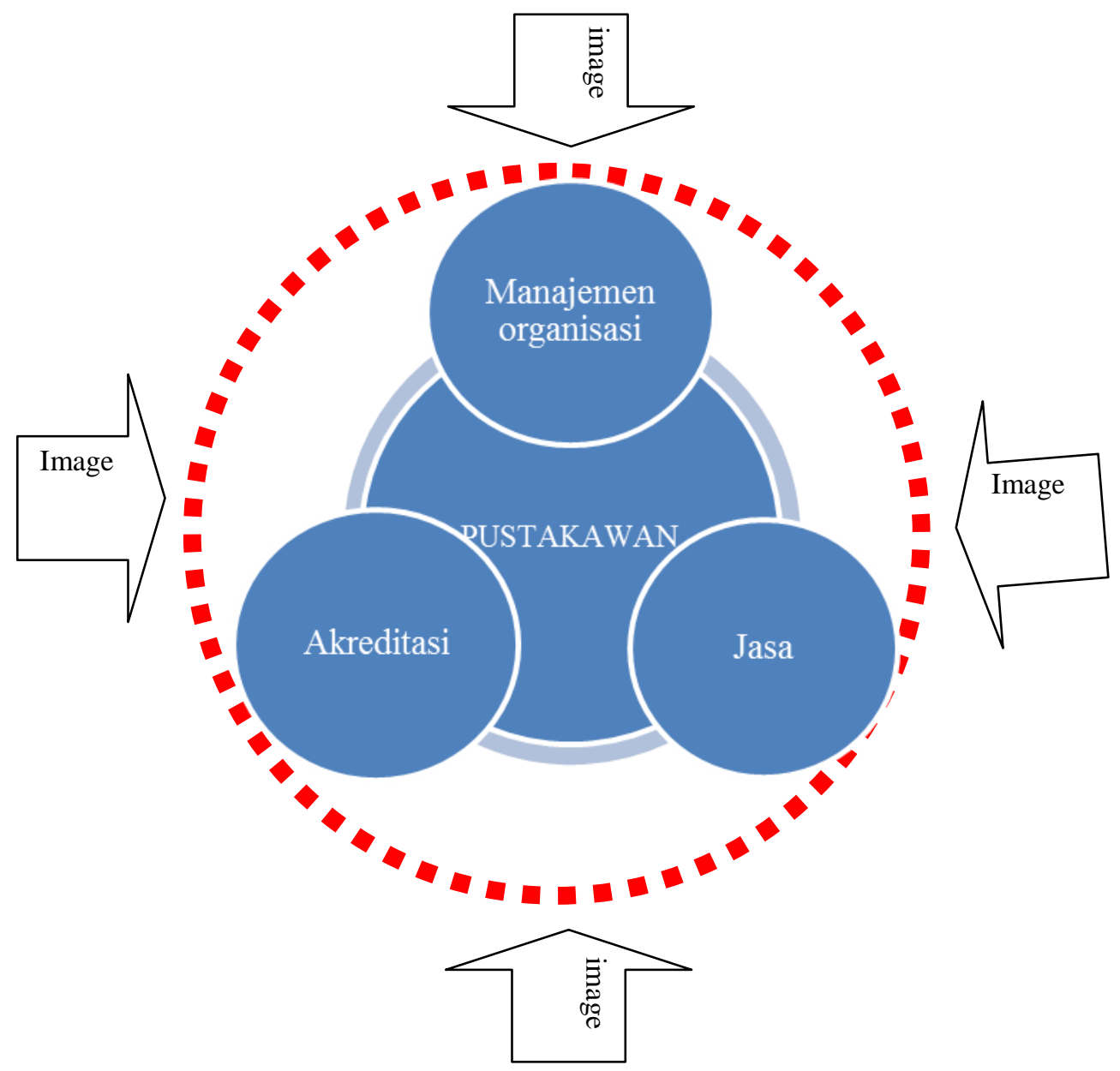

Gambar1: Lingkup perpustakaan

\section{B. HASIL DAN PEMBAHASAN}

\section{Pustakawan dalam Manajemen Perpustakaan}

Menurut Jo Bryson (1990:4) yang dikutip oleh Lasa (2005: 3) dikatakan bahwa manajemen perpustakaan merupakan upaya pencapaian tujuan dengan pemanfaatan sumber daya manusia, informasi, sistem dan sumber dana dengan tetap memperhatikan fungsi manajemen, peran dan keahlian. Menurut Lasa kembali, bahwa dalam pengertian ini sumber daya manusia (human resources) dan non manusia seperti dana teknik, fisik, perlengkapan, alam, informasi, ide, peraturan dan teknologi sangat penting dan diperlukan. Sumber daya tersebut kemudian dikelola melalui proses 
manajemen meliputi perencanaan, pengorganisasian, kepemimpinan dan pengendalian yang kemudian diharapkan mampu mengeluarkan produk berupa barang dan jasa.

Pustakawan masuk sebagai salah satu komponen manajemen, dan sekaligus juga memerankan dirinya sebagai pengelola manajemen. Artinya, untuk memenuhi syarat manajemen berkualitas, eksistensi pustakawan menjadi salah satu sarat utama. Dalam operasional selanjutnya pustakawan bahkan yang mengendalikan proses manajemen. Mulai dari perencanaan, pengorganisasian, kepemimpinan dan pengendalian.

Hampir semua aktifitas perpustakaan berangkat dari manajemen. Mulai dari visi-misi, struktur organisasi, sumber daya, rencana program, kegiatan dan evaluasi semua ada dalam domain manajemen. Pustakawan sebagai salah satu komponen sumber daya perpustakaan berperan strategis dalam menentukan kualitas perpustakaan. Hal ini pernah diungkapkan pula oleh Lasa (2010: 57) bahwa maju mundurnya perpustakaan tergantung pada kualitas sumber daya manusia.

Ruang lingkup manajemen perpustakaan cukup komplek dan luas. Peran pustakawan dalam manajemen dpat dipahami mulai dari perencanaan. Perencanaan adalah acuan segala aktifitas perpustakaan. Mulai dari penetapan visi, misi dan tujuan, program kerja dan kegiatan, perumusan segala kebijakan dan realisasi dan pengembangan perencanaan. Semua akan melibatkan pustakawan dalam menentukan arah kebijakan, menetapkan sampai pada realisasi dan evaluasi. Hal itu disebabkan karena dalam tataran konsep, aksi dan evaluasinya pustakawan dianggap lebih memiliki kemampuan profesional sesuai bidangnya.

Ambil contoh dalam perencanaan pembangunan fisik gedung perpustakaan, keterlibatan pustakawan menjadi sangat penting. Sebab hanya pustakawan yang lebih memahami kebutuhan dan fungsi ruang. Banyak penelitian yang sudah memberikan bukti nyata keterlibatan pustakawan dalam hal ini. Seperti hasil penelitian Arief Nurohman (2010: iv), yang menyimpulkan bahwa pustakawan berperan sebagai penghubung dan pemberi masukan dalam proses renovasi dan pembangunan gedun perpustakaan. Penelitian lain tentang gedung perpustakaan yang dilakukan oleh Aris Nurohman (2009: 105) juga memberikan rekomendasi tentang perlunya kerjasama pustakawan dan arsitek gedung dalam menentukan kebutuhan ruang, dan penataanya sehingga dapat memenuhi kebutuhan dan harapan pemustaka sekaligus efektifitas kerjanya. 
Demikian juga dalam pengorganisasian perpustakaan. Sebagaimana menurut Lasa $(2005 ; 275)$, Pengorganisasian merupakan penyatuan langkah dari seluruh kegiatan yang akan dilaksanakan oleh elemen-elemen suatu lembaga. Dikatakan bahwa pengorganisasin suatu perpustakaan akan berjalan baik apabila memiliki sumber daya, dana, prosedur, koordinasi dan pengarahan pada langkah tertentu. Pustakawan sebagai salah satu sumber daya tidak bisa dinafikan keterlibatannya dalam proses pengorganisasian mulai dari tahap perumusan tujuan, pembagian kerja, pembagian wewenang, kesatuan komando dan koordinasi.

Termasuk dalam kepemimpinan perpustakaan. Pemerintah melalui peraturan pemerintah nomor 24 tahun 2014 pasal 39 butir 1 secara jelas menyebutkan bahwa jabatan kepala perpustakaan berasal dari pustakawan.. Berdasarkan peraturan tersebut menunjukan bahwa kepemipinan perpustakaan berhubungan dengan kompetensi yang harus dimiliki personal dan professional dalam bidangnya.

Dari beberapa hasil penelitian tadi dapat disimpulkan bahwa pustakawan sebagai tenaga profesional memiliki kemampuan dan atau peran dalam manajemen. Sebab manajemen perpustakaan terkait langsung dengan kepustakawanan. Hampir seluruh komponen manajemen perpustakaan melibatkan peran pustakawan. Fenomena ini ibarat sebuah hubungan kausalitas sebab akitbat. Artinya, jika manajemen baik maka ada disebabkan adanya pustakawan yang profesional, sebaliknya jika pustakawanya kurang profesional maka akan berdampak pada manajeman perpustakaan yang kurang baik. Perpustakaan dengan manajemennya adalah cerminan profesional-tidaknya pustakawan yang ada didalamnya.

\section{Pustakawan Dan Jasa Layanan Perpustakaan}

Dalam kesimpulan penelitian yang dilakukan oleh Muhammad Abdillah Islami, Dinn Wahyudin dan Hada Hidayat Margana (2016: 10), menyebutkan bahwa dimensi affect of service (kinerja petugas dalam layanan), berhubungan dengan citra perpustakaan. Sehingga menyimpulkan tentang perlunya peningkatan pengetahuan dibidang kepustakawanan dan layanan.

Jika ruh dari perpustakaan adalah layanan prima kepada pemustaka, maka baik-buruknya penilaian tentang perpustakaan bergantung erat pada kualitas pelayan. Pustakawan sebagai profesional yang dituntut memiliki kompetensi personal dalam bidang layanan menjadi kunci kualitas perpustakaan. Sebagaimana menurut Murphy (1991: 5) yang menyebutkan syarat kompetensi personal pustakawan salah satunya adalah dapat 
melakukan layanan secara prima. Hal senada dikatakan pula oleh Endang Fatmawati (2010: 174) bahwa baik buruknya pelayanan seorang pustakawan kepada pemustaka salah satunya sangat dipengaruhi oleh kepribadian pustakawan.

Dalam literatur lain sebagaimana hasil penelitian tentang faktor pengaruh kompetensi dan kinerja pustakawan khusus bagian referensi yang dilakukan oleh Joseph O. Omoniyi (2003) yang menyimpulkan: reference service is, indeed, a demanding, an intellectual, and brain tasking aspect of library services to clientele. Layanan referensi menuntut kemampuan intelektual dan aspek kerja otak kepada pemustaka. Artinya, ketika pustakawan tidak mampu melakukan layanan referensi, maka itu akan berdampak negatif terhadap kepuasan pemustaka. Dampak negatif ini tidak hanya sebatas penilaian pustakawannya, melainkan juga dapat membawa nama institusi perpustakaan yang menaunginya.

Sangat disayangkan jika dalam sebuah perpustakaan megah secara fisik namun tidak didukung dengan kemampuan pustakawan dalam memberikan jasa layanan prima kepada pemustaka. Kemegahan fisiknya hanya menjadi simbolisme kulit luar yang tidak bisa mencerminkan kualitas isi didalamnya. Inilah tuntutan besar pustakawan untuk terus meningkatkan profesionalitasnya. Sebagaimana menurut Vivi Wardah Ruwaidah (2009: 9) bahwa kompetensi pustakawan secara professional dalam hal layanan harus tercermin dalam unjuk kinerja melalui pengetahuan isi sumber daya informasi, subyek khusus dan mampu mengembangankan dan pengelolaan jasa informasi yang nyaman, mudah diakses dan murah.

Menurut Ruwaidah juga, (2009: 9) bahwa kriteria lain sebagai syarat kompetensi professional bagi pustakawan adalah kemampuan menggunakan teknologi informasi, kemampuan menghasilkan produk informasi, kemampuan mengevaluasi informasi dan melakukan kajian tentang manajemen infromasi, penggunaan informasi dan menjawab tantangan perkembangan bidang jasa informasi, serta terlibat dalam organisasi baik menjadi anggota dan tim senior atau konsultan bidang informasi.

Tantangan profesionalitas pustakawan semacam itu tentu memiliki alasan yang kuat. Terkait dengan itu seorang professor bidang kepustakawanan dan manajemen infromasi, Sheila Corall dalam Paul Genoni \& Graham Walton ed. (2005) mengatakan: technological, organizational and educational changes are significantly affecting the library and information profession. Secara signifikan, perubahan teknologi, organisasi dan pendidikan mempengaruhi perpustakaan dan profesi informasi. Pernyataan 
ini jelas menunjukan adanya tuntutan pengembangan profesi yang berkelanjutan. Dalam konteks perpustakaan, maka peran pustakawan sangat mempengaruhi perkembangan perpustakaan itu sendiri. Dengan bahasa lain, kualitas perpustakaan dipengaruhi oleh profesionalitas pustakawannya.

Inilah yang menjadi inti dari relasi antara perpustakaan dan pustakawan sebagai tenaga professional yang ada didalamnya. Ketergantungan perpustakaan kepada para pustakawan disatu sisi, dan disisi lain kinerja pustakawan adalah produktifitas layanan informasi yang mencerminkan kualitas perpustakaannya.

Apalagi di jaman globalisasi sekarang ini dimana booming informasi dan perkembangan pesat media sejalan dengan perkembangan teknologi informasi, memanjakan manusia dalam berbagai inovasi pemanfaatan teknologi. Tidak dapat dipungkiri, bahwa tuntutan pemustaka beriring dengan itu. Ini menjadi tantangan sekaligus pematangan profesionalisme pustakawan. Bukan menjadi hambatan, melainkan harus menjadi tanggungjawab profesi. Sebab professional tidak berhenti pada pendidikan formal yang pernah ditempuh sebelumnya, melainkan ada keberlanjutan pengembangan professional. Dalam istilah baru disebut sebagai continuing professional development (CPD).

Melalui CPD, maka pustakawan professional akan selalu beradaptasi dengan perkembangan dan perubahan yang terjadi, sehingga produk jasa layanan yang diberikan dan ada diperpustakaan tidak akan usang. Sebaliknya jika ternyata pustakawannya sendiri tidak responsif terhadap pekembangan, maka perpustakaanpun akan ikut terdampak.

\section{Pustakawan dan Akreditasi Perpustakaan}

Masih bersingungan dengan peran pustakawan dan kualitas perpustakaan dikatakan oleh Monique B. Liston (2012), bahwa librarian involvement in the magnet process is vital to an organization attempting to achieve the transformation required for accreditation. Keterlibatan pustakawan dalam proses daya tarik penting bagi sebuah organisasi yang berusaha untuk bertransformasi yang diperlukan untuk akreditasi. Pernyataan ini menggambarkan tentang berkontribusi pustkawan dalam penilaian akreditasi perpustakaan, bahkan akreditasi institusi lembaga induknya, seperti contoh di perguruan tinggi.

Dalam akreditasi khusus perpustakaan seluruh komponen penilaian berasal dari semua unsur yang ada di perpustakaan. Saat akreditasi program studi di perguruan tinggi, ada beberapa unsur penilaian yang sumbernya dari 
perpustakaan, yaitu tenaga pustakawan dan manajemen perpustakaan. Tenaga pustakawan memiliki bobot skore nilai yang dipertimbangkan, dan minimal harus memiliki satu orang berlatar belakang pendidikan S2 ilmu perpustakaan sebagai syarat nilai maksimal. Untuk manajemen perpustakaan terkait langsung dengan manajemen koleksi dan layanan pemustaka.

Ada beberapa alasan mengapa perpustakaan diakreditasi diantarana adalah untuk mengukur kinerja perpustakaan berdasarkan standar yang sudah dibuat. Dengan akreditasi ada semacam kendali mutu dalam sistem kontrol penyelenggaraan perpustakaan. selanjutnya, akan lebih rinci lagi jika melihat dari semua komponen instrumen penilaian dalam akreditasi perpustakaan, hampir semuanya adlaah bagian dari hasil dari kinerja atau performa pustakawan. Oleh karena itu, peran dan kontribusi pustakawan dalam menyiapkan akreditasi perpustakaan adalah sangat penting. Pendapat ini sejalan dengan usulaan dari Khusnul Khotimah (2016: 334), yang menyatakan, agar akreditasi perpustakaan perguruan tinggi mendapatkan nilai maksimal, maka pustakawan harus berperan aktif.

Dengan demikian melihat kualitas perpustakaan berarti melihat bagaimana tingkat profesionalitas pustakawan yang ada didalamnya. Keseluruhan kerja profesionalnya merupakan komponen yang saling berkaitan merangkai bangunan nilai sebuah perpustakaan itu sendiri.

\section{KESIMPULAN}

Profesionalisme adalah spirit atau sikap hidup yang arus dimiliki pustakawan sehingga mampu menempatkan ketrampilan, keahlian dan kecerdasan baik intelektual maupun moralnya didalam aktifitas dan pekerjaan. Dengan semangat menjunjung tinggi profesionalisme maka kegiatan dan aktifitas pustakawan di dalam perpustakaan dapat memberikan kontribusi yang nyata dan berkualitas baik dalam pengelolaan manajemen perpustakaan, produk layanan yang diberikan untuk pemustaka serta mendukung proses akreditasi.

Berdasarkan data yang terhimpun dan diolah melalui penalaahan sebagaimana telah dipaparkan sebelumnya dapat disimpulkan bahwa parameter kualitas perpustakaan dapat dilihat dari satu komponen perpustakaan yaitu pustakawan. Pustakawan sebagai professional di bidang peprustakaan memiliki tanggungjawab secara intelektual, moral dan sosial dalam membangun dan mengembangkan perpustakaan. Tanggungjawab ini terpikul dalam usungan dan wujud aksi nyata di perpustakaan. Berbekal ketrampilan (Skill) yang dimiliki, pengetahuan (knowledge) yang dikuasai, 
kecerdasan intelektual, moral dan sosial yang seluruhnya merupakan bagian dari syarat profesi.

Sehingga pada akhir tulisan ini menyimpulkan bahwa perpustakaan merupakan teropong dari profesionalisme pustakawan. Segala sesuatu baik berwujud fisik, aktifitas, atau kegiatan yang terjadi dan atau dijalankan, terlihat dan atau dirasakan oleh pemustaka adalah merupakan manifestasi dari unjuk kerja (performance) pustakawan. Dengan istilah lain, kualitas perpustakaan akan tercermin dari profesionalisme pustakawan mencerminkan kualitas perpustakaan.

\section{DAFTAR RUJUKAN}

Danim. Sudarwan (2012). Pengembangan Profesi Guru Dari Prajabatan Induksi ke Profesional Madani. Jakarta: Kencana Prenada Media.

Fatmawati, Endang (2010). The art of library: ikatan esai bergizi tentang seni mengelola perpustakaan. Semarang: Badan penerbit universitas diponegoro.

Genoni, Paul and Walton, Graham. Continuing Professional Development-Preparing for New Roles in Libraries: A Voyage of Discovery, edited by Paul Genoni and Graham Walton, vol. 116, K. G. Saur, 2005, p. [4]. IFLA Publications 116. Gale Virtual Reference Library, go.galegroup.com. Diakses 8 Maret 2017.

Handoko, Hani (2001). Manajemen Personalia Dan Sumber Daya Manusia. Jakarta: BPFE

Islami, Muhammad Abdillah dkk. (2016). Analisis tingkat kepuasan pemustaka tentang kualitas layanan perpustakaan dengan menggunakan metode Libqual+ (studi komparatif di perpustakaan pusat instutut teknologi Bandung). Jurnal Edulib, volume 1 edisi 75, Juni 2016.

Joseph O. Omoniyi (2003). Factors influencing competence and performance of reference librarian in academic libraries in Nigeria. E-Journal The Reference Librarian, volume 37: 77, hlm 169-176. Diakses melalui eresources.perpusnas.go.id. tanggal 7 maret 2017.

Khotimah, Khusnul (2016). Eksistensi pustakawan dalam meningkatkan kualitas perpustakaan perguruan tinggi melalui akreditasi perpustakaan. Jurnal Libraria IAIN Kudus, volume 4, nomor 2, Desember 2016.

K.G. Saur. (2008). Measuring quality; performance measurement in libraries, $2 d$ rev.ed. Reference and Research Book News, 23(2) 
sumber dari : https://search.proquest.com/docview/ 199711395? accountid $=25704$

Lasa HS (2005). Manajemen Perpustakaan. Yogyakarta: Gama Media.

Liston, Monique B. Librarian involvement in magnet criteria: a focus on new knowledge, innovations and improvement. Jurnal elektronik, Journal of Hospitality Librarianship. 12: 112-119, 2012. Diakses melalui eresources.perpusnas.go.id tanggal 1 Maret 2017.

Muhajir, Noeng (2011). Metode Penelitian. Ed VI. Yogyakarta: Rake Sarahin.

Murphy (1991). Preface in Spesial Libraries Association Future Competencies of the Information Proffesionals. Washington DC: SLA Occasional Paper Series.

Nurohman, Aris (2009). Gedung perpustakaan: fungsi dan simbolismenya menurut pemustaka studi kasus di sekolah tinggi agama Islam negeri Purwokerto. Jakarta: Universitas Indonesia.

Nurrohman, Arief (2010). Peran pustakawan dalam renovasi dan pembangunan gedung perpustakaan: studi kasus pada miriam budhhardjo resource center, public health information center dan perpustakaan psikologi UI. Jakarta: Universitas indonesia.

Peraturan Pemerintah nomor 24 tahun 2014 Tentang Pelaksanaan UndangUndang Nomor 43 tahun 2007 tentang Perpustakaan. Jakarta: Perpustakaan Nasional

Purwono (2014). Profesi Pustakawan. Jakarta: Universitas Terbuka

Ruwaidah, Vivi Wardah (2009). Kompetensi pustakawan perpustakaan khusus: studi kasus pusat perpustakaan dan penyebaran teknologi pertanian Bogor. Jurnal Perpustakaan Pertanian Bogor, volume 18, nomor 1 halaman 7.

Undang-Undang No. 43 Tahun 2007 Tentang Perpustakaan. Jakarta: Perpustakaan Nasional. 